\title{
Maritime Aerosol Network as a component of Aerosol Robotic Network
}

\author{
A. Smirnov, ${ }^{1,2}$ B. N. Holben, ${ }^{2}$ I. Slutsker, ${ }^{1,2}$ D. M. Giles, ${ }^{1,2}$ C. R. McClain, ${ }^{3}$ T. F. Eck,,${ }^{2,4}$ \\ S. M. Sakerin, ${ }^{5}$ A. Macke,${ }^{6}$ P. Croot,${ }^{6}$ G. Zibordi, ${ }^{7}$ P. K. Quinn, ${ }^{8}$ J. Sciare, ${ }^{9}$ S. Kinne, ${ }^{10}$ \\ M. Harvey, ${ }^{11}$ T. J. Smyth, ${ }^{12}$ S. Piketh, ${ }^{13}$ T. Zielinski, ${ }^{14}$ A. Proshutinsky, ${ }^{15}$ J. I. Goes, ${ }^{16}$ \\ N. B. Nelson, ${ }^{17}$ P. Larouche, ${ }^{18}$ V. F. Radionov, ${ }^{19}$ P. Goloub,${ }^{20}$ K. Krishna Moorthy, ${ }^{21}$ \\ R. Matarrese, ${ }^{22}$ E. J. Robertson, ${ }^{23}$ and F. Jourdin ${ }^{24}$
}

Received 7 October 2008; revised 12 January 2009; accepted 23 January 2009; published 21 March 2009.

[1] The paper presents the current status of the Maritime Aerosol Network (MAN), which has been developed as a component of the Aerosol Robotic Network (AERONET). MAN deploys Microtops handheld Sun photometers and utilizes the calibration procedure and data processing (Version 2) traceable to AERONET. A web site dedicated to the MAN activity is described. A brief historical perspective is given to aerosol optical depth (AOD) measurements over the oceans. A short summary of the existing data, collected on board ships of opportunity during the NASA Sensor Intercomparison and Merger for Biological and Interdisciplinary Oceanic Studies (SIMBIOS) Project is presented. Globally averaged oceanic aerosol optical depth (derived from island-based AERONET measurements) at $500 \mathrm{~nm}$ is $\sim 0.11$ and Angstrom parameter (computed within spectral range $440-870 \mathrm{~nm}$ ) is calculated to be $\sim 0.6$. First results from the cruises contributing to the Maritime Aerosol Network are shown. MAN ship-based aerosol optical depth compares well to simultaneous island and near-coastal AERONET site AOD.

Citation: Smirnov, A., et al. (2009), Maritime Aerosol Network as a component of Aerosol Robotic Network, J. Geophys. Res., 114, D06204, doi:10.1029/2008JD011257.

\section{Introduction}

[2] The World Ocean produces a large amount of natural aerosols that have an impact on the Earth's albedo and climate. Sea salt is the major contributor to aerosol optical depth over the oceans [Mahowald et al., 2006; Chin et al., 2002; Satheesh et al., 1999; Winter and Chylek, 1997] and therefore affects the radiative balance over the ocean through the direct [Haywood et al., 1999] and indirect

\footnotetext{
${ }^{1}$ Science Systems and Applications, Inc., Lanham, Maryland, USA.

${ }^{2}$ Biospheric Sciences Branch, NASA Goddard Space Flight Center, Greenbelt, Maryland, USA.

${ }^{3}$ Ocean Sciences Branch, NASA Goddard Space Flight Center, Greenbelt, Maryland, USA.

${ }^{4}$ Goddard Earth Sciences and Technology Center, University of Maryland, Baltimore County, Baltimore, Maryland, USA.

${ }^{5}$ Institute of Atmospheric Optics, Siberian Branch, Russian Academy of Sciences, Tomsk, Russia.

${ }^{6}$ Leibniz Institute of Marine Sciences, University of Kiel, Kiel, Germany.

${ }^{7}$ Institute for Environment and Sustainability, Joint Research Centre, European Commission, Ispra, Italy.

${ }^{8}$ Pacific Marine Environmental Laboratory, NOAA, Seattle, Washington, USA.

${ }^{9}$ Laboratoire des Sciences du Climat et de l'Environnement, Gif-surYvette, France.

${ }^{10}$ Institute for Meteorology, University of Hamburg, Hamburg, Germany.

Copyright 2009 by the American Geophysical Union. 0148-0227/09/2008JD011257\$09.00
}

aerosol effect [O'Dowd et al., 1999]. Aerosols over the oceans (produced marine and advected from land sources) are important for various atmospheric processes [Lewis and Schwartz, 2004] and remote sensing studies [Gordon, 1997].

[3] Recent publications emphasizing aerosol trends over the oceans based on the long-term satellite records [Mishchenko et al., 2007; Chylek et al., 2007; Remer et

\footnotetext{
${ }^{11}$ National Institute of Water and Atmospheric Research, Wellington, New Zealand.

${ }^{12}$ Plymouth Marine Laboratory, Plymouth, UK

${ }^{13}$ Climatology Research Group, University of the Witwatersrand, Johannesburg, South Africa.

${ }^{14}$ Institute of Oceanology, Polish Academy of Sciences, Sopot, Poland

${ }^{15}$ Woods Hole Oceanographic Institution, Woods Hole, Massachusetts, USA.

${ }^{16}$ Bigelow Laboratory for Ocean Sciences, West Boothbay Harbor, Maine, USA.

${ }^{17}$ Institute for Computational Earth System Science, University of California, Santa Barbara, California, USA.

${ }^{18}$ Institut Maurice-Lamontagne, Mont-Joli, Quebec, Canada.

${ }^{19}$ Arctic and Antarctic Research Institute, Saint Petersburg, Russia.

${ }^{20}$ Laboratoire d'Optique Atmosphérique, Université des Sciences et Techniques de Lille, Villeneuve d'Ascq, France.

${ }^{21}$ Space Physics Laboratory, Vikram Sarabhai Space Centre, Trivandrum, India.

${ }^{22}$ Department of Physics, University of Bari, Bari, Italy.

${ }^{23}$ Department of Oceanography, University of Cape Town, Cape Town, South Africa.

${ }^{24}$ Service Hydrographique et Oceanographique de la Marine, Brest, France.
} 

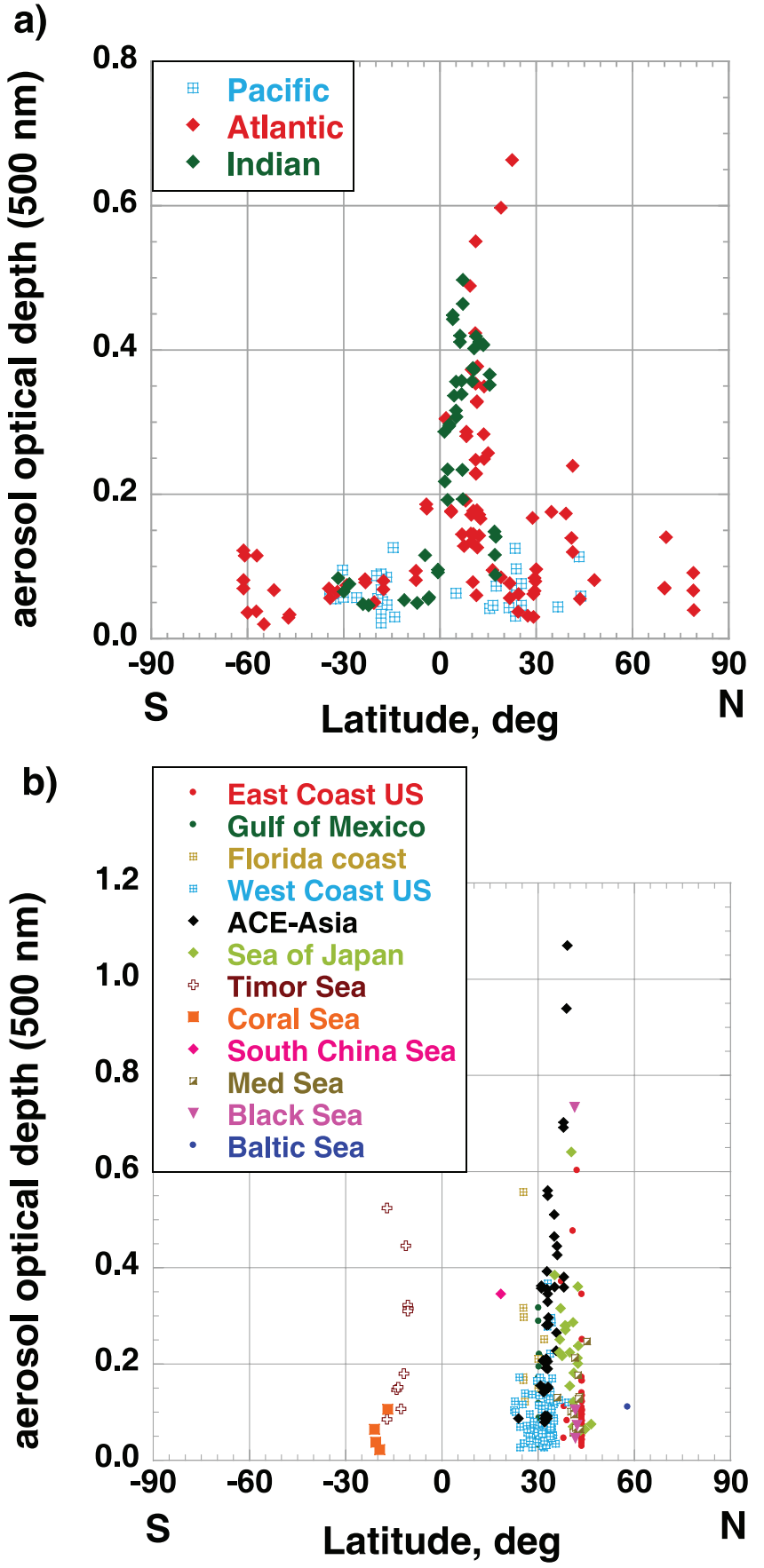

Figure 1. Daily averages of aerosol optical depth collected during the SIMBIOS program in the (a) open oceanic and (b) coastal areas.

al., 2008] and the quantitative difference between aerosol climatologies derived from various sensors [Kahn et al., 2007; Liu and Mishchenko, 2008] have further increased the demand for more data.

[4] Aerosol optical depth measurements over the oceans began in the 1960s and over the years accumulated a significant amount of information from individual scientific cruises [Smirnov et al., 2002] as well as from complex regional experiments [Quinn and Bates, 2005]. Aerosol optical depth data analysis in conjunction with information on synoptic air mass types and back trajectories [see, e.g.,
Hoppel et al., 1990; Reddy et al., 1990; Smirnov et al., 1995] has shown the potential of this simple but effective optical class discrimination technique. Statistically significant differences however, were found only between optical properties of continental and maritime air mass types.

[5] A comprehensive survey of shipborne measurements conducted over the last 30-40 years was published by Smirnov et al. [2002]. What did we learn from the historical record? Published results of aerosol optical depth measurements over the oceans provided an important milestone for future understanding. Despite data scarceness, calibration uncertainty, and sometimes unknown accuracy, those data sets facilitated (at least to some extent) a better perception of aerosol optical properties over the remote oceanic areas, inland seas, and areas affected by dust sources from Africa and industrial pollution sources in Europe and North America. Coastal data emphasized the tremendous difficulties faced in establishing even regional aerosol climatologies. This historical database was successfully employed by Ignatov et al. [1995] in regional analysis and by Liu et al. [2004] in the global validation of two channel AVHRR aerosol optical depth retrievals.

[6] In the current paper we present brief analysis of the historical SIMBIOS ship-borne and AERONET islandbased aerosol optical depth data, describe the concept of MAN, and show first results from the cruises contributing to the Maritime Aerosol Network.

\section{SIMBIOS Data}

[7] The SIMBIOS (The Sensor Intercomparison for Marine Biological and Interdisciplinary Ocean Studies) program [Mueller et al., 1998; McClain and Fargion, 1999] began in 1997 and through 2003 collected data on aerosol optical depth over the oceans from various ships of opportunity using Microtops II handheld Sun photometers. Measurement strategy and protocol, ship tracks, and statistics for various aerosol types and regions were presented in the paper by Knobelspiesse et al. [2004]. The SIMBIOS database was revisited in order to better understand where we still have gaps in our knowledge on aerosol optical properties over the oceans. Daily averages were computed for all available cruises and after some additional screening data were divided into two subsets: oceanic and coastal (acquired within $100-150 \mathrm{~km}$ from the nearest shoreline). Additional quality control (screening) was typically minimal; however during one of the cruises aerosol optical depth demonstrated a consistent unusual spectral dependence, which implied calibration or instrumental problems. As a result these suspect data were removed from further consideration. Overall 458 measurement days spanning a 6-year period (1997-2003) were considered. Latitudinal distribution of aerosol optical depth at $500 \mathrm{~nm}$ is presented in Figure 1a for the oceanic subset and in Figure 1b for the coastal subset. The oceanic data have been divided roughly by longitude between three oceans: Pacific $\left(70^{\circ} \mathrm{W}-150^{\circ} \mathrm{E}\right)$, Atlantic $\left(20^{\circ} \mathrm{E}-70^{\circ} \mathrm{W}\right)$ and Indian $\left(20^{\circ} \mathrm{E}-150^{\circ} \mathrm{E}\right)$.

[8] Figure 1a shows that measurements in the Pacific Ocean were mainly limited to the latitudinal belt $30^{\circ} \mathrm{N}-30^{\circ} \mathrm{S}$ and $\tau_{a}(500 \mathrm{~nm})$ were close to the typical remote ocean value of 0.06-0.07 [Smirnov et al., 2002] Several Atlantic transects contributed to more dense data 
a)

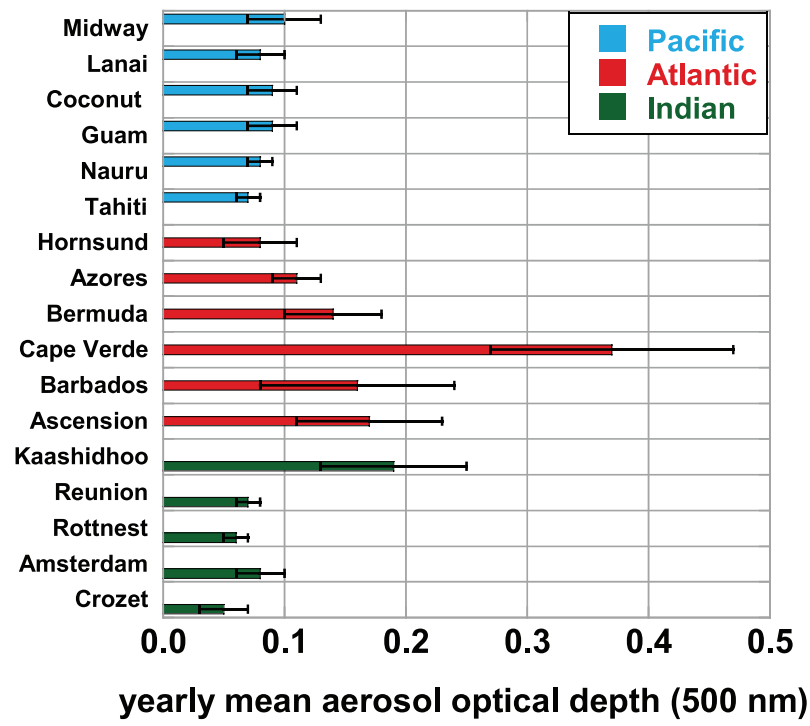

b)

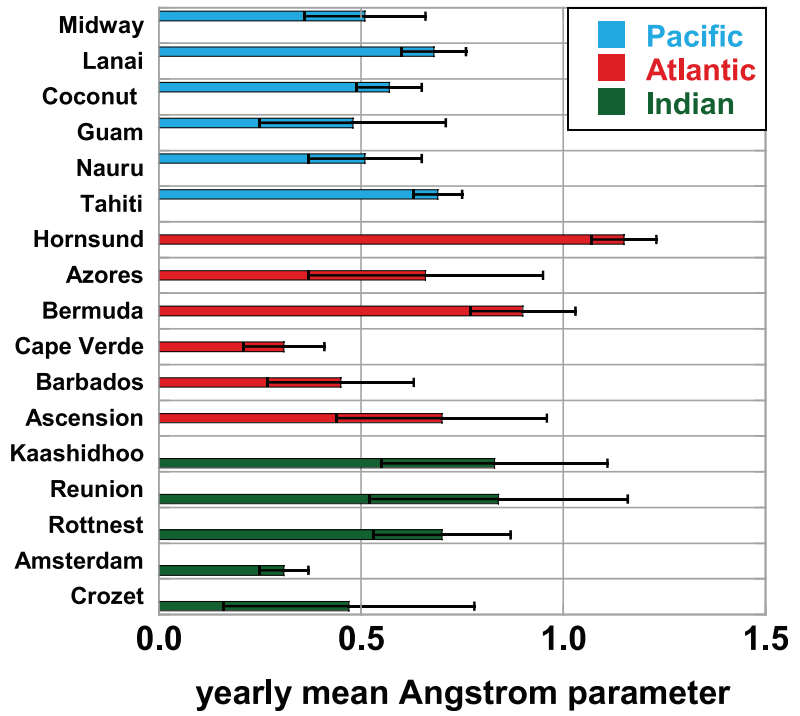

Figure 2. AERONET island-based multiyear statistics. Yearly means of (a) aerosol optical depth at $500 \mathrm{~nm}$ and (b) Angstrom parameter.

coverage close to the equator with very little data collected north of $45^{\circ} \mathrm{N}$ and south of $30^{\circ} \mathrm{S}$. One can observe the typical pronounced maximum in $\tau_{a}$ within the area in the Northern Hemisphere influenced by Saharan dust (primarily $\left.0^{\circ}-25^{\circ} \mathrm{N}\right)$. Aerosol optical depth in that region is highly variable and has a strong intra-annual (seasonal) dependence. In the remote Atlantic not influenced by Saharan dust or pollution from continents, aerosol optical depth values did not exceed 0.10 , being on average $\sim 0.07$. Measurements in the Indian Ocean showed high turbidity near the Indian peninsula. However, those measurements were limited to the northeast monsoon season, when continental pollution is transported from the Indian subcontinent region to the Arabian Sea and Indian Ocean. The eastern part of the Indian Ocean and areas south of $30^{\circ} \mathrm{S}$ were not covered and still lack any data from oceanic ships.

[9] Data acquisition efforts in the coastal areas were concentrated on the east coast and West Coast of the United States. Very few data (almost none) are available for inland seas (Mediterranean, Baltic, Black, Persian Gulf) and other coastal areas, except for the region near the coast of Japan intensively studied during the ACE-Asia experiment, though within a limited timeframe (March-April 2001). Figure $1 \mathrm{~b}$ shows relatively stable optical conditions on the West Coast with $\tau_{a}(500 \mathrm{~nm})$ less than 0.20 and a variety of aerosol loadings on the east coast where optical depth ranged from 0.05 to 0.60 . Pollution and dust aerosol dominated aerosol optical properties during the ACE-Asia experiment and aerosol optical depth in some instances was over 1.00. The latitudinal dependence shown in Figure 1b presents a clear picture that despite the tremendous effort in data collection the gaps dominate and therefore suggests how little we know.

\section{AERONET Data}

[10] The Aerosol Robotic Network (AERONET) is a world-wide network of Sun/sky radiometers that operates over 300 sites worldwide [Holben et al., 1998]. Starting in 1996 AERONET has a number of operational island sites. Several publications based on the AERONET data [Holben et al., 2001; Eck et al., 2001, 2005; Smirnov et al., 2000, 2002, 2003a, 2003b] have analyzed aerosol optical properties over the oceans, including pollution and dust aerosol transport affecting and modifying those properties. Accumulated statistics on aerosol optical depth and Angstrom parameter afforded estimation of the globally averaged parameters over the oceans (from island-based measurements). Yearly mean aerosol optical depth and Angstrom parameter for various island sites are shown in Figures $2 \mathrm{a}$ and $2 b$. Horizontal bars represent plus or minus one standard deviation. Locations of these AERONET sites are shown in Figure 3, while Table 1 presents coordinates, measurement period, and number of measurement days used in the statistics. Data quality level 2.0 was used for all sites except for Reunion.

[11] It is noteworthy that yearly mean $\tau_{a}(500 \mathrm{~nm})$ was less 0.10 for all sites in the Pacific. Slightly elevated $\tau_{a}$ over Midway $(\sim 0.10)$ most likely is associated with the springtime Asian dust transport [Eck et al., 2005]. In fact when the spring (March through May) dust transport months are excluded the remaining 9-month average at Midway $\sim 0.09$. The AERONET record for the Atlantic shows a strong latitudinal dependence and optical depth is highly variable. Hornsund is located on Spitzbergen in the Arctic $\left(77^{\circ} \mathrm{N}\right)$ and yearly average $\tau_{a}$ there $(\sim 0.08$, this is only for 7 months owing to polar night) is very close to the remote marine conditions, despite the presence of Arctic haze (from advected pollutants) in the spring months [Shaw, 1995]. Saharan dust transport strongly affects the aerosol optical properties over Cape Verde and Barbados. Industrial pollution can modify maritime aerosol over Bermuda and the Azores. Seasonal dust and biomass burning aerosol transport frequently influences the Ascension Island optical depth. The record for the Indian Ocean sites was not as long as for the Pacific and Atlantic. Optical depth data over 


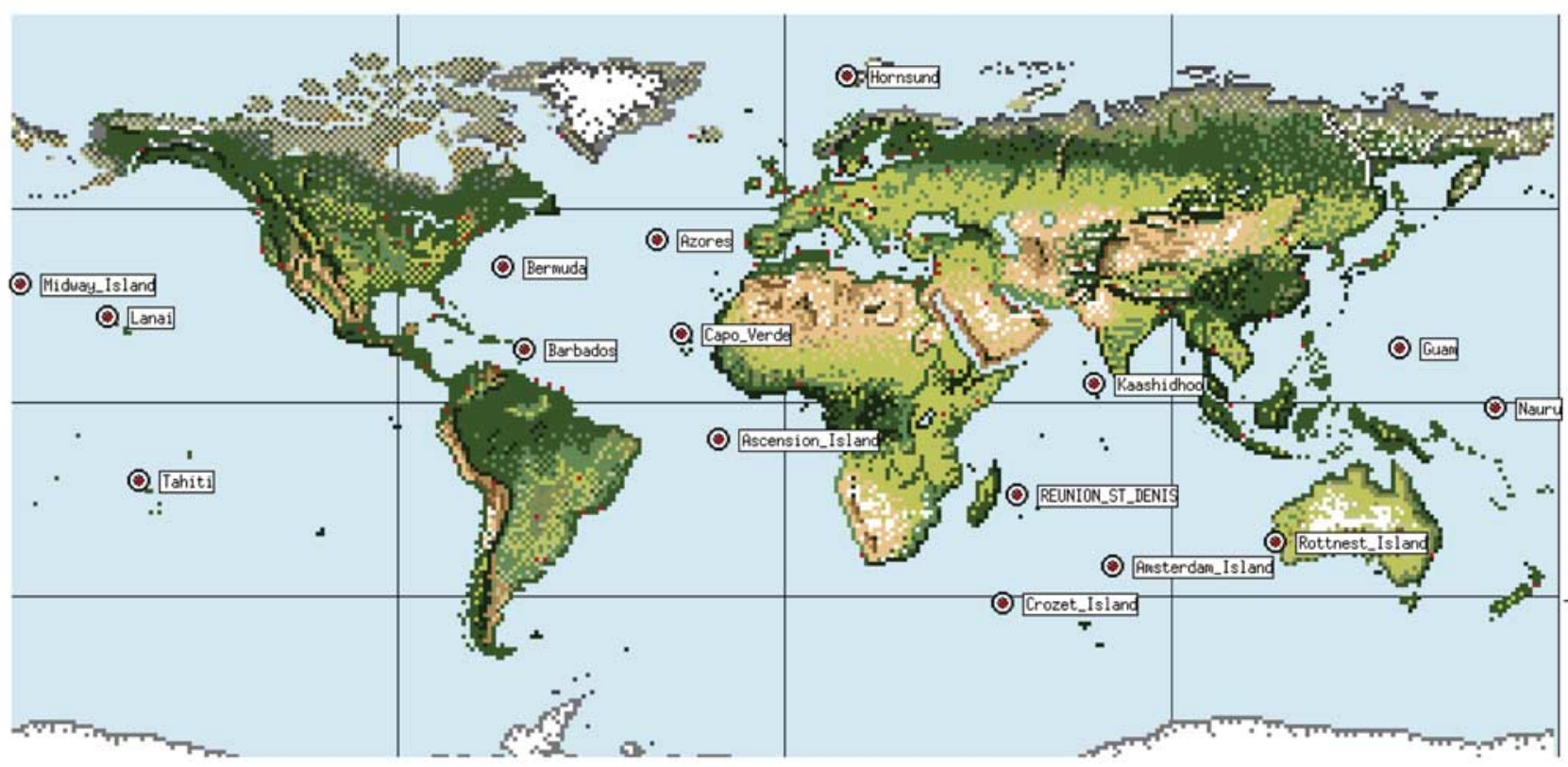

Figure 3. Distribution of island-based AERONET sites.

Kaashidhoo (Maldives) were collected primarily during the dry season when the northeast monsoon brought heavily polluted air from the Indian subcontinent. A modest record from other sites in the subtropical and midlatitude Southern Indian Ocean yielded average $\tau_{a} \sim 0.05-0.08$.

[12] We computed globally averaged $\tau_{a}(500 \mathrm{~nm})$ and Angstrom parameter $\alpha$ (based on a spectral range 440$870 \mathrm{~nm}$; computed by log linear regression of 440-, 500-, 675- and $870-\mathrm{nm}$ data, except for a few instruments that lacked the $500-\mathrm{nm}$ channel) by simply weighting the mean optical parameter for a particular ocean with the area fraction of that ocean basin (see Table 2). Data acquired over Hornsund were considered representative for the Arctic Ocean and ship-based data reported by Smirnov et al.

Table 1. AERONET Data Used in This Study

\begin{tabular}{llcr}
\hline \multicolumn{1}{c}{ Site } & \multicolumn{1}{c}{$\begin{array}{c}\text { Latitude, } \\
\text { Longitude }\end{array}$} & $\begin{array}{c}\text { Measurement } \\
\text { Period }\end{array}$ & $\begin{array}{c}\text { Number } \\
\text { of Days }\end{array}$ \\
\hline Midway Island & $28^{\circ} 12^{\prime} \mathrm{N} 177^{\circ} 22^{\prime} \mathrm{W}$ & $\begin{array}{c}2001-2002 ; \\
2005-2006\end{array}$ & 661 \\
Lanai & $20^{\circ} 44^{\prime} \mathrm{N} 156^{\circ} 55^{\prime} \mathrm{W}$ & $1996-2004$ & 1467 \\
Coconut Island & $21^{\circ} 26^{\prime} \mathrm{N} 157^{\circ} 47^{\prime} \mathrm{W}$ & $2000-2004$ & 956 \\
Guam & $13^{\circ} 25^{\prime} \mathrm{N} 144^{\circ} 48^{\prime} \mathrm{E}$ & 2006 & 154 \\
Nauru & $00^{\circ} 31^{\prime} \mathrm{S} 166^{\circ} 54^{\prime} \mathrm{E}$ & $1999-2006$ & 998 \\
Tahiti & $17^{\circ} 34^{\prime} \mathrm{S} 149^{\circ} 36^{\prime} \mathrm{W}$ & $1999-2007$ & 1184 \\
Hornsund & $77^{\circ} 00^{\prime} \mathrm{N} 15^{\circ} 33^{\prime} \mathrm{E}$ & $2005-2007$ & 151 \\
Azores & $38^{\circ} 31^{\prime} \mathrm{N} 28^{\circ} 37^{\prime} \mathrm{W}$ & $2000-2004$ & 481 \\
Bermuda & $32^{\circ} 22^{\prime} \mathrm{N} 64^{\circ} 41^{\prime} \mathrm{W}$ & $1996-2001$ & 832 \\
Cape Verde & $16^{\circ} 43^{\prime} \mathrm{N} 22^{\circ} 56^{\prime} \mathrm{W}$ & $1994-2007$ & 2708 \\
Barbados & $13^{\circ} 09^{\prime} \mathrm{N} 59^{\circ} 37^{\prime} \mathrm{W}$ & $1996-2000$ & 751 \\
Ascension Island & $07^{\circ} 58^{\prime} \mathrm{S} 14^{\circ} 24^{\prime} \mathrm{W}$ & $1998-2006$ & 1569 \\
Kaashidhoo & $04^{\circ} 57^{\prime} \mathrm{N} 73^{\circ} 27^{\prime} \mathrm{E}$ & $1998-2000$ & 546 \\
Reunion & $20^{\circ} 53^{\prime} \mathrm{S} 55^{\circ} 29^{\prime} \mathrm{E}$ & $2006-2007$ & 237 \\
Rottnest Island & $32^{\circ} 00^{\prime} \mathrm{S} 115^{\circ} 30^{\prime} \mathrm{E}$ & $2001-2004$ & 497 \\
Amsterdam Island & $37^{\circ} 48^{\prime} \mathrm{S} 77^{\circ} 34^{\prime} \mathrm{E}$ & $2003-2005 ; 2007$ & 212 \\
Crozet Island & $46^{\circ} 26^{\prime} \mathrm{S} 51^{\circ} 51^{\prime} \mathrm{E}$ & $2005-2007$ & 94 \\
\hline
\end{tabular}

${ }^{\mathrm{a}}$ Data quality level 2.0 was used for all sites except for Reunion.
[2006] were taken as an estimate for the Southern Ocean. Although most stations are located in the tropics and subtropics we think those estimates (Table 2) might be useful.

[13] It should be noted that the small number of AERONET stations on islands combined with the very nonuniform distribution of islands in the oceans likely results in significant sampling biases. Therefore one may argue that the geographical sampling from AERONET is insufficient to give accurate ocean based averages. However, it arguably yields a detail of discrimination for many atmospheric optical applications. Overall parameters shown in Figure 2 and listed in Table 2 are admissible and physically acceptable; they are based on the best currently available statistics and represent our current knowledge from island-based AERONET measurements.

[14] The AERONET-based oceanic globally averaged $\tau_{a}(500 \mathrm{~nm})$ is $\sim 0.11(\sigma \sim 0.04)$; this value is very close to the satellite record reported by Remer et al. [2008] (0.13 for Aqua and 0.14 for Terra), Zhang et al. [2008] (0.12 for NAAPS with the assimilated MODIS data), Mishchenko et

Table 2. Average Optical Parameters Based on the AERONET Data

\begin{tabular}{lccccc}
\hline Ocean & $\tau_{a}(500 \mathrm{~nm})^{\mathrm{a}}$ & $\sigma_{\tau \mathrm{a}}{ }^{\mathrm{b}}$ & $\alpha^{\mathrm{c}}$ & $\sigma_{\alpha}{ }^{\mathrm{d}}$ & $\begin{array}{c}\text { Area } \\
\text { Fraction }\end{array}$ \\
\hline Pacific & 0.085 & 0.010 & 0.573 & 0.091 & 0.46 \\
Atlantic & 0.190 & 0.103 & 0.604 & 0.229 & 0.23 \\
Indian & 0.090 & 0.057 & 0.560 & 0.203 & 0.20 \\
Arctic & 0.080 & 0.030 & 1.150 & 0.180 & 0.04 \\
Southern & 0.060 & 0.020 & 0.380 & 0.280 & 0.06 \\
Global & 0.108 & 0.042 & 0.597 & 0.161 & \\
\hline
\end{tabular}

${ }^{\mathrm{a}}$ Mean value of aerosol optical depth at a wavelength $500 \mathrm{~nm}$.

${ }^{\mathrm{b}}$ Standard deviation of the aerosol optical depth.

${ }^{\mathrm{c}}$ Mean value of the Angstrom parameter.

${ }^{\mathrm{d}}$ Standard deviation of the Angstrom parameter. 
al. [2007] (0.11 for AVHRR), Myhre et al. [2005] (0.100.16 for AVHRR, SeaWiFS, MODIS), and Zhao et al. [2005] (0.11-0.16 for AVHRR and MODIS). Coarse particles of the marine sea salt and continental dust aerosol reduced the Angstrom parameter (mean of 0.6) and made it lower by a factor of 2 compared to typical $\alpha$ values $(\sim 1.3-1.7)$ over continental regions that are not affected by desert dust [see, e.g., Holben et al., 2001].

\section{Maritime Aerosol Network Status}

[15] Accurate knowledge of atmospheric aerosol optical properties is a key to the success of atmospheric correction over the oceans. The NASA Workshop "Supporting in-situ and space-based measurements" (Montréal, Quebec, 67 October 2006) helped to formulate scientific questions and research challenges needing to be addressed: current atmospheric aerosol models should be updated and more data over the oceans should be collected. Therefore, the principal question of this workshop could be formulated as follows: what is to be done to improve our knowledge of aerosol optical properties over the oceans and fill the existing data gaps. We suggested the establishment of the Maritime Aerosol Network which would be a component of the Aerosol Robotic Network (AERONET), and would be affiliated with the AERONET calibration and data processing standards and procedures. The proposed activity evolved around handheld Sun photometer measurements from various ships of opportunity (scientific and nonscientific) and will complement island-based AERONET measurements, thus extending data collection to the vast regions where no islands exist. The principal scientific objectives of this kind of activity are climate change studies (direct and indirect forcing); satellite retrieval validation; verification of global aerosol transport model simulations; atmospheric correction in ocean color studies; and also questions of the existing gaps in global aerosol distribution and how representative are the island measurements.

[16] In order to address those challenges we have reestablished NASA's ship-based optical depth measurement network (SIMBIOS was discontinued in 2003); developed an archival system within the AERONET browser, but specifically designed for "moving" objects: ships; developed a calibration protocol; incorporated Microtops data files into AERONET general processing, utilizing AERONET's Version 2 processing algorithm; and developed a centralized archiving and distribution: public domain webbased access.

[17] The Microtops II Sun photometer is a handheld device specifically designed to measure columnar optical depth and water vapor content [Morys et al., 2001]. The direct Sun measurements are acquired in five spectral channels within the spectral range $340-1020 \mathrm{~nm}$. The bandwidths of the interference filters vary from 2 to $4 \mathrm{~nm}$ (UV channels) to $10 \mathrm{~nm}$ for visible and near-infrared channels. Detailed description of the Sun photometer and types of errors involved are given by Morys et al. [2001], Porter et al. [2001], Ichoku et al. [2002], and Knobelspiesse et al. [2003, 2004]. The estimated uncertainty of the optical depth in each channel does not exceed plus or minus 0.02 , which is slightly higher than the uncertainty of the AERONET field (not master) instruments as shown by Eck et al.
[1999]. A GPS should be connected to the Sun photometer to obtain the time of measurements and geographical position of the ship.

[18] Each Microtops instrument is calibrated against an AERONET master-CIMEL Sun/sky radiometer at GSFC, which was calibrated from morning Langley plot measurements on Mauna Loa. As a rule we put a master CIMEL in a manual mode that enables it to take direct Sun measurements every minute. The Microtops then takes 20-30 consecutive scans within an approximately 5- to 6-min interval, side by side with the master CIMEL. It is highly desirable to make intercalibration measurements in clear (with AOD at $500 \mathrm{~nm}$ less than 0.25) and stable atmospheric conditions to ensure accurate and stable results. Figure 4 presents a calibration window that indicates that standard deviation of the aerosol optical depth during the calibration process (based on the CIMEL measurements) is less than 0.005. Aerosol optical depths and their standard deviations are shown for the master instrument (Figure 4, top) and calibrated Microtops (Figure 4, bottom) for a time period of several minutes. New and old "extraterrestrial signal constants" are displayed with variation coefficients (standard deviation/mean; in percent) for each spectral channel. The last column indicates the temporal change in calibration coefficients (in percent). Aerosol optical depth is retrieved by applying the AERONET processing algorithm (Version 2) to the raw data [Smirnov et al., 2004] (http://aeronet.gsfc. nasa.gov/new_web/Documents/version2_table.pdf).

[19] In the MAN relational database a Microtops Sun photometer status window provides information on the instrument current status, date it was returned from the field, filter configuration and parameters $\mathrm{A}$ and $\mathrm{B}$ required for the water vapor content retrievals, calibration dates (postfield and prefield calibrations), maintenance remarks (cleaning, filter change, etc.), data status, shipping information, and information regarding the person responsible for the data collection. Figure 5 presents a spreadsheet of the Microtops instrument pool current status as of August 2008.

[20] Regular measurements in various oceanic regions started in late 2006 to early 2007 and are currently continuing and expanding. All collected data are available on the Internet at http://aeronet.gsfc.nasa.gov/new_web/maritime aerosol_network.html.

[21] The measurement protocol is very simple and requires an operator taking 5-6 consecutive scans (it takes slightly over a minute to complete the sequence) when the solar disk is free of clouds. It is important to note that observers are relied upon to decide when the Sun is unobscured by clouds (based on visual assessment only) and to only take measurements for those conditions. Depending on the sky conditions, measurements should be repeated several times during the day.

[22] Measurement points are grouped temporally into series. If the interval between two points in a measurement sequence is more than two minutes, then these points are placed into different series (Figure 6). A series can have one or more measurement points (typically five or more). A series is considered a single data point (an average of the measurement points in the group); and a sequence of series in a day may be used to compute the daily average.

[23] Data quality is assured in the following way. The Level 1.0 (unscreened) measurement series are formed from 


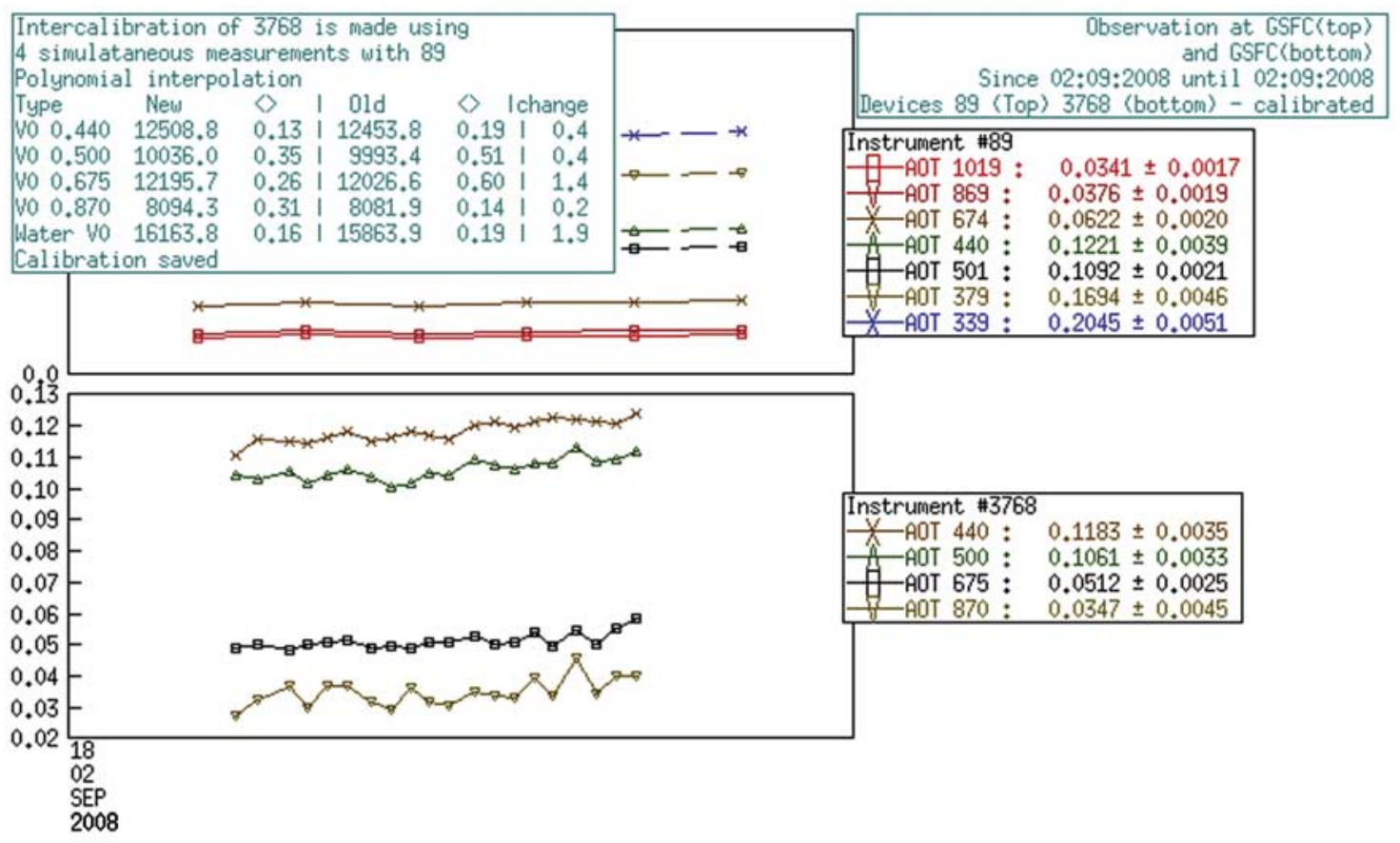

Figure 4. The intercalibration window: (top) AERONET master CIMEL, and (bottom) calibrated Microtops.

Level 1.0 points. The cloud and pointing error screening is applied to Level 1.0 data to produce a Level 1.5 data set. The following criteria are examined for cloud and pointing errors: (1) Within a series, the minimum aerosol optical depth for each point is identified at each wavelength $\left(\tau_{a i}^{\min }\right)$. (2) If the difference $\left(\tau_{a i}-\tau_{a i}^{\mathrm{min}}\right)$ for each spectral channel is less than the maximum of $\left\{\tau_{a i}^{\min } * 0.05,0.02\right\}$, then that point within a series is considered cloud-free and pointing error free. If the above screening removes all but one point from a series, then an additional criterion below is applied to the spectral channels: (3) If the Angstrom parameter computed using all available channels between 440 and $870 \mathrm{~nm}$ is greater than -0.1 , then the point is considered cloud and pointing error free.
[24] The Level 1.5 data series are raised to Level 2.0 (quality-assured) series after final calibration values are applied, spectral channels are evaluated for filter degradation and other possible instrumental problems or data anomalies; and manual data inspection is completed for possible cloud contaminated outliers.

[25] For each cruise we generate a map, where in a compact graphic form (filled squares), daily averages at a wavelength of $500 \mathrm{~nm}$ and the ship's track are shown. Data files are available in the following form: instantaneous measurements (Level 1.0), instantaneous measurements (Level 1.5), series (groups) of measurements (Level 1.5), and daily averages (Level 1.5). Ship tracks are available in the form of geospatial Google Earth files and mapped daily

\begin{tabular}{|c|c|c|c|c|c|c|c|c|c|c|c|c|c|}
\hline \multicolumn{3}{|c|}{ INTERCAL } & \multirow{2}{*}{$\begin{array}{c}\text { ACTIVE } \\
\text { PREVIOUS }\end{array}$} & \multirow[t]{2}{*}{ NEW } & \multirow[t]{2}{*}{ SEARCH $s$} & \multirow[t]{2}{*}{ ORT } & \multirow[t]{2}{*}{ HOME } & \multirow[t]{2}{*}{ EGEND } & \multirow{2}{*}{\multicolumn{2}{|c|}{ HELP }} & \multirow[b]{3}{*}{ Received } & \multirow[b]{3}{*}{ Contact Person } & \multirow[b]{3}{*}{ Current Status } \\
\hline & Total & 22 & & & & & & & & & & & \\
\hline Inst & S_N & Date & Filters & A B Constants & Sun1 & Data Status & Maint & Clean & Sun2 & Shipped & & & \\
\hline 470 & 3768 & 5/12/2008 & $440,500,675,870,936$ & $\mathrm{~A}=0.6928 \mathrm{~B}=0.604$ & $x$ & & & $\mathrm{x}$ & $x$ & $6 / 12 / 2008$ & $6 / 18 / 2008$ & Joaquim Goes & Bering Sea \\
\hline 472 & 3765 & 6/4/2008 & $440,500,675,870,936$ & $\mathrm{~A}=0.6749 \mathrm{~B}=0.6024$ & & & & $x$ & $x$ & 6/17/2008 & $6 / 23 / 2008$ & Peter Croot & Atlantic Ocean \\
\hline 473 & 5395 & 5/19/2008 & $440,500,675,870,936$ & $A=0.6597 \mathrm{~B}=0.5899$ & $x$ & & & $x$ & $x$ & & & & GSFC \\
\hline 474 & 5396 & $3 / 13 / 2008$ & $440,500,675,870,936$ & $A=0.6088 B=0.5825$ & $x$ & & & $x$ & $\mathrm{x}$ & $3 / 28 / 2008$ & $4 / 7 / 2008$ & Tymon Zielinski & Sopot, Poland \\
\hline 475 & 3770 & $7 / 25 / 2008$ & $440,500,675,870,936$ & $\mathrm{~A}=0.6928 \mathrm{~B}=0.604$ & $x$ & & & $x$ & $x$ & & & & GSFC \\
\hline 476 & 5376 & $7 / 25 / 2008$ & $380,500,675,870,1640$ & & $x$ & & & $x$ & $x$ & 8/12/2008 & $8 / 12 / 2008$ & Lorraine Remer & GSFC \\
\hline 481 & 3125 & $7 / 25 / 2008$ & $340,440,675,870,936$ & $A=0.6548 B=0.574$ & $\bar{x}$ & & & $x$ & $x$ & & & & GSFC \\
\hline 482 & 3657 & 6/30/2008 & $340,440,675,870,936$ & $\mathrm{~A}=0.6749 \mathrm{~B}=0.602$ & $x$ & & & $x$ & $x$ & $8 / 11 / 2008$ & & Tony Bromley & New Zealand \\
\hline 483 & 3755 & 1/28/2008 & $440,500,675,870,936$ & $A=0.6928 B=0.604$ & $x$ & & & $x$ & $x$ & $3 / 3 / 2008$ & $3 / 10 / 2008$ & Pierre Larouche & Quebec, Canada \\
\hline 484 & 3759 & $7 / 25 / 2008$ & $340,440,675,870,936$ & $\mathrm{~A}=0.6928 \mathrm{~B}=0.602$ & $x$ & & & $x$ & $x$ & & & & GSFC \\
\hline 485 & 3766 & 7/1/2008 & $440,500,675,870,936$ & $\mathrm{~A}=0.6928 \mathrm{~B}=0.604$ & $x$ & & & $x$ & $x$ & & & & GSFC \\
\hline 486 & 3767 & 12/3/2007 & $440,500,675,870,936$ & $A=0.6928 B=0.604$ & $x$ & & & $x$ & $x$ & 12/26/2007 & $1 / 3 / 2008$ & Zhanqing $L$ & China \\
\hline 487 & 3771 & $777 / 2008$ & $440,500,675,870,936$ & $\mathrm{~A}=0.6928 \mathrm{~B}=0.604$ & $x$ & & & $x$ & $x$ & & & & GSFC \\
\hline 488 & 3774 & 6/6/2008 & $440,500,675,870,936$ & $A=0.6928 B=0.604$ & $x$ & & & $x$ & $x$ & 6/25/2008 & $7 / 3 / 2008$ & Giuseppe Zibordi & Gulf of Bothnia \\
\hline 489 & 3775 & $5 / 28 / 2008$ & $440,500,675,870,936$ & $\mathrm{~A}=0.6928 \mathrm{~B}=0.604$ & $x$ & & & $x$ & $x$ & $6 / 25 / 2008$ & $7 / 6 / 2008$ & Andrey Proshutinsky & Beaufort Sea \\
\hline 490 & 3769 & 3/4/2008 & $440,500,675,870,936$ & $\mathrm{~A}=0.6928 \mathrm{~B}=0.604$ & $x$ & & $x$ & $x$ & $x$ & 5/14/2008 & $6 / 24 / 2008$ & George Tolkachenko & Sevastopol, Ukraine \\
\hline 501 & 4080 & $6 / 6 / 2008$ & $380,400,500,675,870$ & & $x$ & & & $x$ & $x$ & $7 / 3 / 2008$ & $777 / 2008$ & Patricia Quinn & Seattle, WA \\
\hline 502 & 3803 & $6 / 6 / 2008$ & $380,400,500,675,870$ & & $x$ & & & $x$ & $x$ & $7 / 3 / 2008$ & $777 / 2008$ & Patricia Quinn & Seattle, WA \\
\hline 503 & 3763 & 7/25/2008 & $340,440,675,870,936$ & $A=0.6928 B=0.604$ & $x$ & & & $x$ & $x$ & $8 / 12 / 2008$ & $8 / 12 / 2008$ & Lorraine Remer & GSFC \\
\hline 507 & 4079 & $7 / 22 / 2008$ & $380,400,500,675,870$ & & $x$ & & & $x$ & $x$ & $8 / 12 / 2008$ & & Ken Voss & Miami, FL \\
\hline 508 & 7388 & 7/28/2008 & $500,675,870,936,1020$ & $\mathrm{~A}=0.6548 \mathrm{~B}=0.574$ & $x$ & & & $x$ & $x$ & & & Arnon Karnieli & GSFC \\
\hline 509 & 12601 & $8 / 11 / 2008$ & $440,500,675,870,1020$ & & $x$ & & & & & & & Giuseppe Zibordi & GSFC \\
\hline
\end{tabular}

Figure 5. Microtops status window. 
Measurements Grouped into Series

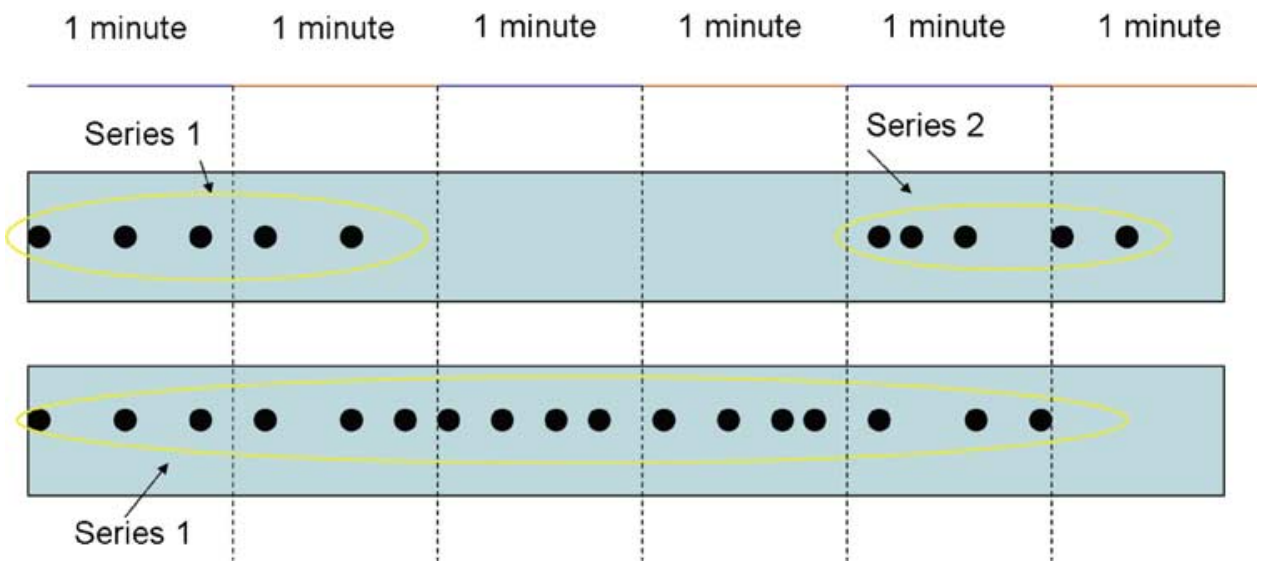

Figure 6. Data processing scheme: measurements points grouped into series.

averages at various wavelengths are available in the same compressed file. Cruise notes (if any) made by the operators and any other complimentary information (meteorological, satellite, sky photos from a fish-eye camera, etc.) are available also. Upon completion of the Quality Assurance process the data archive will be complemented by the Level 2.0 series and daily averages.

[26] The whole process of instrument calibration, shipment to the ship, data collection at sea, shipment back to GSFC for the postfield calibration, calibration, maintenance, data processing, cloud screening and quality assurance, web site posting and updates, is a very lengthy, time and labor-consuming procedure. The MAN data usage policy emphasizes that the public domain data are contributed by the Maritime Aerosol Network (MAN), a component of the International AERONET Federation; each cruise has Principal Investigators (PIs) responsible for instrument deployment, maintenance and data collection, and the PIs have priority use of the data collected during the ship cruise and are entitled to be notified when using their cruise data. Also we believe that owing to the research and development phase characterizing Maritime Aerosol Network, offering coauthorship to Principal Investigators would be an expected sign of courtesy, however it is not a requirement.

[27] Figure 7 presents the latitudinal dependence of aerosol optical depth in the Atlantic Ocean and in Antarctica based on a number of cruises. Cruise tracks allowed for sampling of several aerosol regimes over the Northern and Southern Atlantic. In remote oceanic areas not influenced by continental aerosol sources the aerosol optical depth is typically below 0.10 at $500 \mathrm{~nm}$. Saharan dust transport in the tropical Atlantic near to the coast of West Africa significantly increased the aerosol loading. Pollution sources in Europe can elevate optical depth in the coastal sampling areas to the north of 30 degrees. Measurements in the Arctic region yielded a low average optical depth $\sim 0.05$. During the Antarctic summer (January 2006 and January-February 2007) aerosol optical depth near the coastline of Antarctica was even lower yet $\sim 0.02-0.03$.

[28] The whole data archive is mapped in Figure 8. Daily averages from various cruises characterize regional aerosol optical depth and overall coverage of the network. Obviously vast oceanic areas still have no or very limited coverage (e.g., in the Pacific and Indian oceans; near the coast of the Southeast Asia; in the Caribbean). Further efforts are needed to evaluate aerosol regimes over those oceanic regions.

[29] Ship-based measurements were compared with the AERONET data obtained from the island and coastal sites along the cruise tracks. Island measurements always posed a question whether data acquired could be considered representative for the ocean areas or if the influence of the continental-generated aerosol and breaking waves along

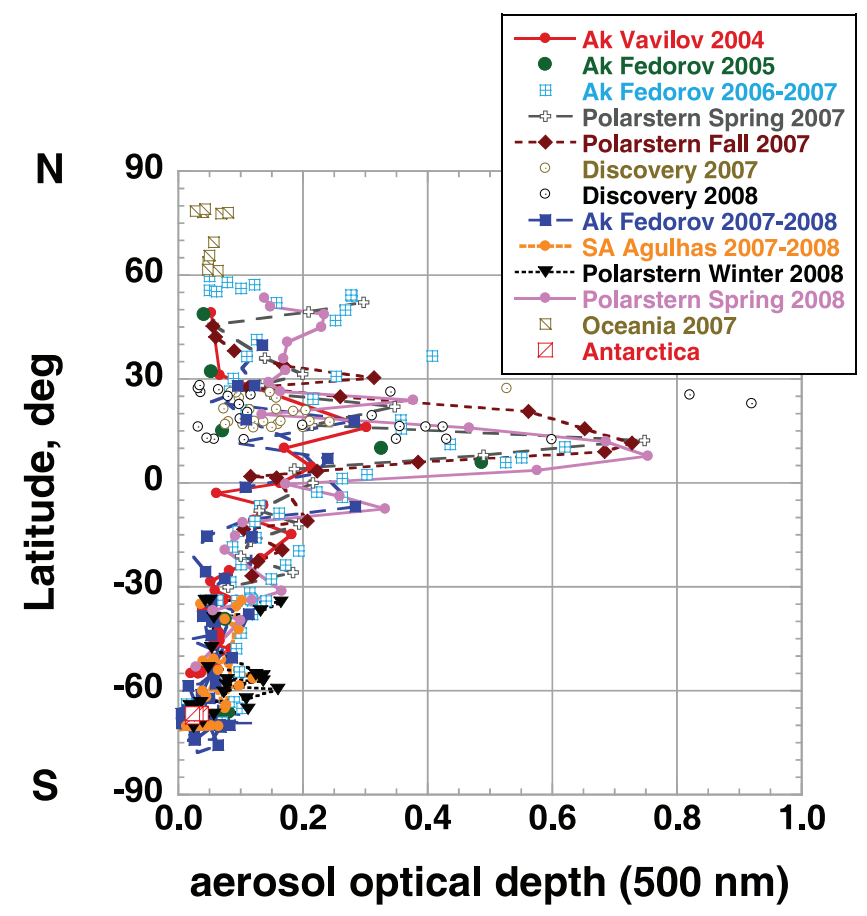

Figure 7. Latitudinal dependence of aerosol optical depth in the Atlantic Ocean. Seasons in the legend correspond to meteorological seasons for Northern Hemisphere. 


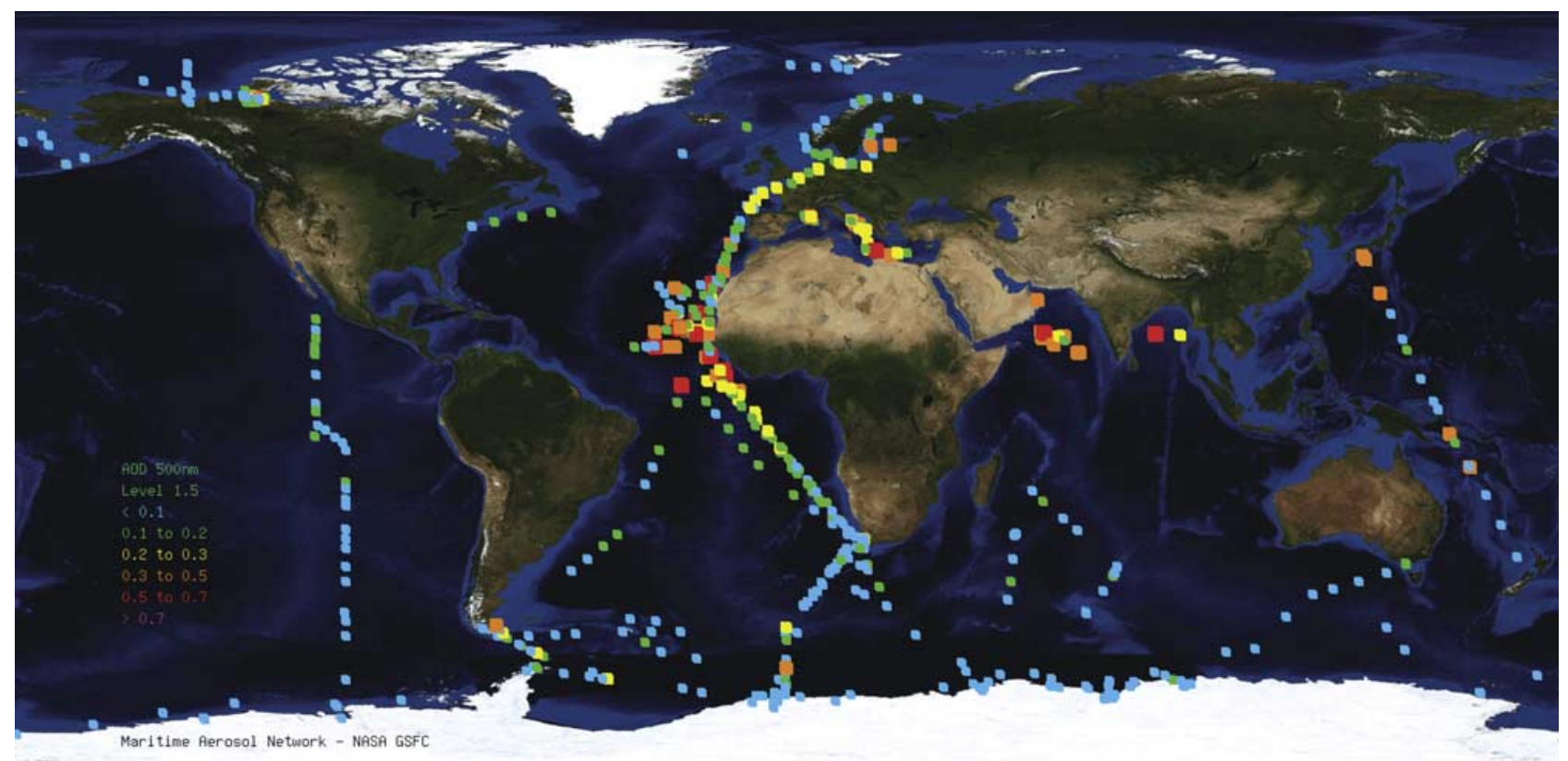

Figure 8. Maritime Aerosol Network global coverage: cruise tracks and daily averages of aerosol optical depth are shown.

the coastline significantly alter columnar atmospheric optical properties. The ship measurements were collocated with the island and coastal oceanic AERONET sites spatially and temporally. We considered ship-based series taken within $200 \mathrm{~km}$ of AERONET sites and observation times matched by less than $1 \mathrm{~h}$. In order to make an adequate comparison we only took into account sites where minimal influence of local sources is expected (thus excluding measurements in the Mediterranean Sea). Comparison results for aerosol optical depth at $440 \mathrm{~nm}$ is presented in Figure 9. Each site is located within $1 \mathrm{~km}$ from the coastline except for Cape Verde $(\sim 4.5 \mathrm{~km})$. The AERONET aerosol optical depths were of Level 1.5 quality in order to enlarge our statistical sample. However, we have checked the data for any additional potential calibration problems, since post deployment calibration has not yet been made in this case. The aerosol optical depth scatterplot does not show any particular bias for both data sets, although we can see a visible cluster of points above the 1:1 line. This cluster was acquired in a highly variable dust outbreak conditions west of Africa in the North Atlantic.

\section{Conclusions}

[30] The Maritime Aerosol Network has been established as a component of the Aerosol Robotic Network. It relies on many logistic and scientific aspects developed within the AERONET Project and compliments island-based measurements. We believe that the Maritime Aerosol Network will provide the scientific community with valuable information on aerosol optical properties over the oceans. The database can be used for climate change and atmospheric radiation budget modeling, satellite validation studies, global and regional aerosol transport modeling, atmospheric correction and ocean color observations, etc. Employing simple, standard and commercially available instrumentation, traceable calibration, a scientifically sound processing scheme and easily accessible web-based public data archive, the network has strong growth potential. Expanded spatial coverage will contribute to enhanced understanding of aerosol optical properties over the oceans and improve our knowledge of physical processes of maritime aerosol production, transport and distribution. The database may help stimulate research and international collaboration in various scientific areas.

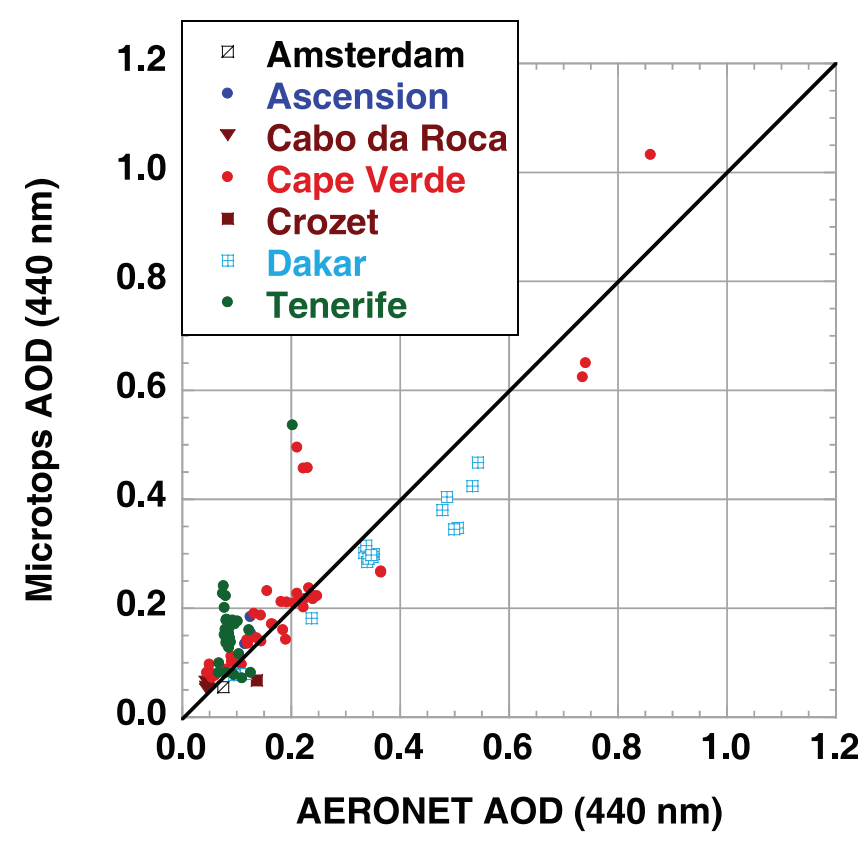

Figure 9. Ship-based and AERONET aerosol optical depth measurement comparison. 
[31] Acknowledgments. The authors thank Hal Maring (NASA Headquarters) for his support of AERONET. The authors would like to acknowledge managerial and operational support from W.W. Newcomb, M. Sorokin, A. Scully, A. Tran, D.A. Siegel, K. Knobelspiesse, D. Hamilton, L. Rainville, A. Jayakumar, S. Schick, and D. Menzies (USA); N.T. O'Neill, C. Bourgeault-Brunelle, and M. Palmer (Canada); M. Panchenko, O. Kopelevich, S. Gulev, D. Kabanov, S. Terpugova, V. Polkin, A Tikhomirov, A. Sinitsyn, Y. Turchinovich, and N. Vlasov (Russia); L. Blarel, J. Nicolas, S. Devidal, L. Martinon, M. Faillot, and C. Petus (France); A. Baker and C. Powell (UK); A. Herber, Y. Zoll, A. Wassmann, and M. Heller (Germany); H. Power, T. Bromley, and R. Martin (New Zealand); J. Piskozub, J. Kowalczyk, and A. Ponczkowska (Poland); D. Williams and B. Kuyper (South Africa); J. Stamnes and S. Iversen (Norway); and K. Niranjan, S. Babu, and S.K. Satheesh (India). We thank the AERONET site managers and the SIMBIOS principal investigators for maintaining the instruments and making collection of these data possible. Jean Sciare would like to thank Institut Polaire Francais (IPEV) and the IPEV-AEROTRACE observatory program for providing technical support and infrastructure. The work of Tymon Zielinski was supported by Polish national grant AERONET59.

\section{References}

Chin, M., P. Ginoux, S. Kinne, B. N. Holben, B. N. Duncan, R. V. Martin, J. A. Logan, A. Higurashi, and T. Nakajima (2002), Tropospheric aerosol optical thickness from the GOCART model and comparisons with satellite and Sun photometer measurements, J. Atmos. Sci., 59, 461-483, doi:10.1175/1520-0469(2002)059<0461:TAOTFT $>2.0 . C O ; 2$

Chylek, P., U. Lohmann, M. Dubey, M. Mishchenko, R. Kahn, and A. Ohmura (2007), Limits on climate sensitivity derived from recent satellite and surface observations, J. Geophys. Res., 112, D24S04, doi:10.1029/2007JD008740

Eck, T. F., B. N. Holben, J. S. Reid, O. Dubovik, A. Smirnov, N. T. O’Neill I. Slutsker, and S. Kinne (1999), Wavelength dependence of the optical depth of biomass burning, urban, and desert dust aerosol, J. Geophys. Res., 104, 31,333-31,350.

Eck, T. F., B. N. Holben, O. Dubovik, A. Smirnov, I. Slutsker, J. M. Lobert, and V. Ramanathan (2001), Column integrated aerosol optical properties over the Maldives during the northeast monsoon for 1998-2000, J. Geophys. Res., 106, 28,555-28,566, doi:10.1029/2001JD000786.

Eck, T. F., et al. (2005), Columnar aerosol optical properties at AERONET sites in central eastern Asia and aerosol transport to the tropical midPacific, J. Geophys. Res., 110, D06202, doi:10.1029/2004JD005274.

Gordon, H. R. (1997), Atmospheric correction of ocean color imagery in the Earth Observing System era, J. Geophys. Res., 102, 17,081-17,106, doi:10.1029/96JD02443.

Haywood, J., V. Ramaswamy, and B. Soden (1999), Tropospheric aeroso climate forcing in clear-sky satellite observation over the oceans, Science, 283, 1299-1303, doi:10.1126/science.283.5406.1299.

Holben, B. N., et al. (1998), AERONET-A federated instrument network and data archive for aerosol characterization, Remote Sens. Environ., 66 , 1-16, doi:10.1016/S0034-4257(98)00031-5.

Holben, B. N., et al. (2001), An emerging ground-based aerosol climatology: Aerosol optical depth from AERONET, J. Geophys. Res., 106 12,067-12,097, doi:10.1029/2001JD900014.

Hoppel, W. A., J. W. Fitzgerald, G. M. Frick, R. E. Larson, and E. J. Mack (1990), Aerosol size distributions and optical properties found in the marine boundary layer over the Atlantic Ocean, J. Geophys. Res., 95 , 3659-3686, doi:10.1029/JD095iD04p03659.

Ichoku, C., et al. (2002), Analysis of the performance characteristics of the five-channel Microtops II Sun photometer for measuring aerosol optical thickness and precipitable water vapor, J. Geophys. Res., 107(D13), 4179, doi:10.1029/2001JD001302.

Ignatov, A. M., L. L. Stowe, S. M. Sakerin, and G. K. Korotaev (1995) Validation of the NOAA/NESDIS satellite aerosol product over the North Atlantic in 1989, J. Geophys. Res., 100, 5123-5132.

Kahn, R. A., M. J. Garay, D. L. Nelson, K. K. Yau, M. A. Bull, B. J. Gaitley, J. V. Martonchik, and R. C. Levy (2007), Satellite-derived aerosol optical depth over dark water from MISR and MODIS: Comparisons with AERONET and implications for climatological studies, J. Geophys. Res., 112, D18205, doi:10.1029/2006JD008175.

Knobelspiesse, K. D., C. Pietras, and G. S. Fargion (2003), Sun-pointing error correction for sea deployment of the Microtops II handheld Sun photometer, J. Atmos. Oceanic Technol., 20, 767-771, doi:10.1175/ 1520-0426(2003)20<767:SPECFS>2.0.CO;2.

Knobelspiesse, K. D., et al. (2004), Maritime aerosol optical thickness measured by handheld Sun photometers, Remote Sens. Environ., 93, 87-106, doi:10.1016/j.rse.2004.06.018.

Lewis, E. R., and S. E. Schwartz (2004), Sea Salt Aerosol Production: Mechanisms, Methods, Measurements, and Models, Geophys. Monogr. Ser., vol. 152, 413 pp., AGU, Washington, D. C.
Liu, L., and M. I. Mishchenko (2008), Toward unified satellite climatology of aerosol properties: Direct comparisons of advanced level 2 aerosol products, J. Quant. Spectrosc. Radiat. Transfer, 109, 2376-2385.

Liu, L., M. I. Mishchenko, I. Geogdzhayev, A. Smirnov, S. M. Sakerin, D. M. Kabanov, and O. A. Ershov (2004), Global validation of twochannel AVHRR aerosol optical thickness retrievals over the oceans, J. Quant. Spectrosc. Radiat. Transfer, 88, 97-109, doi:10.1016/j.jqsrt. 2004.03.031.

Mahowald, N. M., J.-F. Lamarque, X. X. Tie, and E. Wolff (2006), Sea-salt aerosol response to climate change: Last Glacial Maximum, preindustrial, and doubled carbon dioxide climates, J. Geophys. Res., 111, D05303, doi:10.1029/2005JD006459.

McClain, C. R., and G. Fargion (1999), SIMBIOS Project 1999 annual report, NASA Tech. Memo. 1999-209486, 128 pp., NASA Goddard Space Flight Cent., Greenbelt, Md.

Mishchenko, M. I., I. V. Geogdzhayev, W. B. Rossow, B. Cairns, B. E. Carlson, A. A. Lacis, L. Liu, and L. D. Travis (2007), Long-term satellite record reveals likely recent aerosol trend, Science, 315, 1543 , doi:10.1126/science.1136709.

Morys, M., F. M. Mims III, S. Hagerup, S. E. Anderson, A. Baker, J. Kia, and T. Walkup (2001), Design, calibration, and performance of MICROTOPS II handheld ozone monitor and Sun photometer, J. Geophys. Res., 106, 14,573-14,582, doi:10.1029/2001JD900103.

Mueller, J., C. McClain, B. Caffrey, and G. Feldman (1998), The NASA SIMBIOS Program, Backscatter, 9, 29-32.

Myhre, G., et al. (2005), Intercomparison of satellite retrieved aerosol optical depth over ocean during the period September 1997 to December 2000, Atmos. Chem. Phys., 5, 1697-1719.

O’Dowd, C. D., J. A. Lowe, and M. H. Smith (1999), Coupling sea-salt and sulphate interactions and its impact on cloud droplet concentration predications, Geophys. Res. Lett., 26, 1311-1314, doi:10.1029/1999GL900231.

Porter, J. N., M. Miller, C. Pietras, and G. Motell (2001), Ship-based Sun photometer measurements using Microtops Sun photometers, J. Atmos. Oceanic Technol., 18, 765-774, doi:10.1175/1520-0426(2001)018< 0765:SBSPMU $>2.0 . \mathrm{CO} ; 2$.

Quinn, P. K., and T. S. Bates (2005), Regional aerosol properties: Comparison of boundary layer measurements from ACE 1, ACE 2, Aerosols99, INDOEX, ACE Asia, TARFOX, and NEAQS, J. Geophys. Res., 110, D14202, doi:10.1029/2004JD004755.

Reddy, P. L., F. W. Kreiner, J. J. DeLuisi, and Y. Kim (1990), Aerosol optical depths over the Atlantic derived from shipboard sunphotometer observations during the 1988 global change expedition, Global Biogeochem. Cycles, 4, 225-240, doi:10.1029/GB004i003p00225.

Remer, L. A., et al. (2008), Global aerosol climatology from the MODIS satellite sensors, J. Geophys. Res., 113, D14S07, doi:10.1029/2007JD009661. Satheesh, S. K., V. Ramanathan, X. Li-Jones, J. Lobert, I. Podgorny, J. Prospero, B. Holben, and N. Loeb (1999), A model for the natural and anthropogenic aerosols over the tropical Indian Ocean derived from Indian Ocean Experiment data, J. Geophys. Res., 104, 27,421-27,440, doi:10.1029/1999JD900478.

Shaw, G. E. (1995), The Arctic haze phenomena, Bull. Am. Meteorol. Soc., 76, 2403-2413, doi:10.1175/1520-0477(1995)076<2403:TAHP >2.0. $\mathrm{CO} ; 2$.

Smirnov, A., Y. Villevalde, N. T. O’Neill, A. Royer, and A. Tarussov (1995), Aerosol optical depth over the oceans: Analysis in terms of synoptic air mass types, J. Geophys. Res., 100, 16,639-16,650.

Smirnov, A., B. N. Holben, D. Savoie, J. M. Prospero, Y. J. Kaufman, D. Tanre, T. F. Eck, and I. Slutsker (2000), Relationship between column aerosol optical thickness and in situ ground based dust concentrations over Barbados, Geophys. Res. Lett., 27, 1643-1646, doi:10.1029/ 1999GL011336.

Smirnov, A., B. N. Holben, Y. J. Kaufman, O. Dubovik, T. F. Eck, I. Slutsker, C. Pietras, and R. Halthore (2002), Optical properties of atmospheric aerosol in maritime environments, J. Atmos. Sci., 59 $501-523$, doi:10.1175/1520-0469(2002)059<0501:OPOAAI $>2.0$. CO;2.

Smirnov, A., B. N. Holben, O. Dubovik, R. Frouin, T. F. Eck, and I. Slutsker (2003a), Maritime component in aerosol optical models derived from Aerosol Robotic Network data, J. Geophys. Res., 108(D1), 4033 doi:10.1029/2002JD002701.

Smirnov, A., B. N. Holben, T. F. Eck, O. Dubovik, and I. Slutsker (2003b), Effect of wind speed on columnar aerosol optical properties at Midway Island, J. Geophys. Res., 108(D24), 4802, doi:10.1029/2003JD003879.

Smirnov, A., B. N. Holben, A. Lyapustin, I. Slutsker, and T. F. Eck (2004), AERONET processing algorithm refinement, paper presented at AERONET Workshop, NASA, El Arenosillo, Spain.

Smirnov, A., et al. (2006), Ship-based aerosol optical depth measurements in the Atlantic Ocean, comparison with satellite retrievals and GOCART model, Geophys. Res. Lett., 33, L14817, doi:10.1029/2006GL026051.

Winter, B., and P. Chylek (1997), Contribution of sea salt aerosol to the planetary clear-sky albedo, Tellus, Ser. B, 49, 72-79. 
Zhang, J., J. S. Reid, D. L. Westphal, N. L. Baker, and E. J. Hyer (2008), A system for operational aerosol optical depth data assimilation over global oceans, J. Geophys. Res., 113, D10208, doi:10.1029/2007JD009065.

Zhao, T. X.-P., I. Laszlo, P. Minnis, and L. Remer (2005), Comparison and analysis of two aerosol retrievals over the ocean in the Terra/Clouds and the Earth's Radiant Energy System-Moderate Resolution Imaging Spectroradiometer single scanner footprint data: 1. Global evaluation, J. Geophys. Res., 110, D21208, doi:10.1029/2005JD005851.

P. Croot and A. Macke, Leibniz Institute of Marine Sciences at the University of Kiel, D-24105 Kiel, Germany.

T. F. Eck, D. M. Giles, B. N. Holben, I. Slutsker, and A. Smirnov, Biospheric Sciences Branch, Code 614.4, Building 33, Room G406, NASA Goddard Space Flight Center, Greenbelt, MD 20771, USA. (Alexander. Smirnov-1@nasa.gov)

J. I. Goes, Bigelow Laboratory for Ocean Sciences, West Boothbay Harbor, ME 04575, USA.

P. Goloub, Laboratoire d'Optique Atmosphérique, Université des Sciences et Techniques de Lille, F-59650 Villeneuve d'Ascq, France.

M. Harvey, National Institute of Water and Atmospheric Research,

Wellington 6021, New Zealand

F. Jourdin, Service Hydrographique et Oceanographique de la Marine, F-29228 Brest, France.

S. Kinne, Institute for Meteorology, University of Hamburg, D-20146 Hamburg, Germany.

K. Krishna Moorthy, Space Physics Laboratory, Vikram Sarabhai Space Centre, Trivandrum 695022, India.
P. Larouche, Institut Maurice-Lamontagne, Mont-Joli, Quebec, QC G5H $3 Z 4$ Canada.

R. Matarrese, Department of Physics, University of Bari, I-70122 Bari, Italy.

C. R. McClain, Ocean Sciences Branch, NASA Goddard Space Flight Center, Greenbelt, MD 20771, USA.

N. B. Nelson, Institute for Computational Earth System Science, University of California, Santa Barbara, CA 93106, USA.

S. Piketh, Climatology Research Group, University of the Witwatersrand, Johannesburg 2050, South Africa.

A. Proshutinsky, Woods Hole Oceanographic Institution, Woods Hole, MA 02543, USA.

P. K. Quinn, NOAA Pacific Marine Environmental Laboratory, Seattle, WA 98115, USA.

V. F. Radionov, Arctic and Antarctic Research Institute, Saint Petersburg 199397, Russia.

E. J. Robertson, Department of Oceanography, University of Cape Town, Cape Town 7701, South Africa.

S. M. Sakerin, Institute of Atmospheric Optics, Russian Academy of Sciences, Siberian Branch, Tomsk 634055, Russia.

J. Sciare, Laboratoire des Sciences du Climat et de 1'Environnement, F-91191 Gif-sur-Yvette, France.

T. J. Smyth, Plymouth Marine Laboratory, Plymouth PL1 3DH, UK.

G. Zibordi, Institute for Environment and Sustainability, Joint Research Centre, European Commission, I-21027 Ispra, Italy.

T. Zielinski, Institute of Oceanology, Polish Academy of Sciences, 81-712 Sopot, Poland. 